\title{
On clutch size and hatching success of the South American turtles Podocnemis expansa (Schweigger, 1812) and P. unifilis Troschel, 1848 (Testudines, Podocnemididae)
}

\author{
PAULO EMILIO VANZOLINI* \\ Museu de Zoologia, Universidade de São Paulo, 04263-000, São Paulo, SP, Brasil \\ Manuscript received on April 29, 2003; accepted for publication on July 2, 2003.
}

\begin{abstract}
Data on clutch size and hatching success of $P$. expansa were gathered for seven beaches traditionally used by the species and re-analyzed statistically by means of regression analysis, of the number of eggs on the number of females (or nests) and of the number of young on the number of eggs. All regressions were linear, passed through the origin and had excellent fits. Average clutch size varied from 75 to 123 , and presented geographic differentiation: (i) Rio Orinoco, (ii) Rio Trombetas + Rio Branco and (iii) Rio Juruá + Rio Purus. Average hatching success was ca. $83 \%$. In P. unifilis there was also geographic variation in clutch size, the Iquitos area showing the highest values. Hatching success of $P$. unifilis was uniformly high: only one sample, from Iquitos, had less than $90 \%$ success. The outstanding fit of the clutch size regressions leads one to consider egg volume variability, which was found to be high in both species, in contradiction with current optimal egg size theory.
\end{abstract}

Key words: turtle reproduction, hatching success, clutch size, optimal egg-size theory, Podocnemis expansa, Podocnemis unifilis.

\section{INTRODUCTION}

Turtles whose reproductive cycle is geared to the alternation of river flood/low flow are particularly sensitive to the damming of large rivers for hydroelectric projects, which unavoidably involves regularization of regime, and thus obliteration of fluvial cycles. This is the case with the South American species of Podocnemis. They are important animals from multiple angles, biological, esthetical and economic; the problems concerning their conservation are both difficult and urgent. It is possible to assist their reproduction and so to mitigate environmental impacts, but assistance needs to be based on firm ecological grounds.

\footnotetext{
*Member of Academia Brasileira de Ciências E-mail: vanzo@usp.br
}

P. expansa ("tartaruga", turtle par excellence) is a widely distributed (Wermuth and Mertens 1996), very large, even spectacular animal, whose females lay their eggs communally, in herds frequently very numerous, on traditional beaches. It has naturally attracted much attention since early days (e.g., Humboldt 1814). Given its vulnerability, due to gregarious egg-laying, and to irrational human predation, it has been the object of much concern, and effort is currently being spent on conservation.

P. unifilis (tracajá) is a smaller, less spectacular turtle, which does not aggregate as $P$. expansa in large herds at laying time, but is nevertheless a very important staple food. It is available at all times, and the meat and eggs are highly esteemed.

In spite of the commonness of the species, and 
of a considerable amount of printed comment on them, it is remarkable how little hard information is available. The literature is uneven, often unprofessional, scattered, and at times hard to obtain. This paper is an attempt to gather and organize original data from published sources on the reproductive biology of these two forms, specifically on clutch size and hatching success.

Both parameters are important. Clutch size is indispensable to the estimation of reproductive effort, and so to the application of concepts of optimization and trade-off. Hatching success is additionally important from a more practical viewpoint, the evaluation of management techniques, such as transplantation of nests.

\section{MATERIALS AND METHODS}

The data gathered in the literature were mostly raw, not statistically analyzed. As they consist essentially of proportions (number of eggs vs number of females or nests, number of young hatched vs number of eggs laid), and as several independent samples were usually available, I used whenever possible regression analysis, followed by analysis of covariance and by the application of Tukey's test. I did not make use of all data available in the literature, but discarded sets of data that seemed incongruous to me.

All statistical methods are intentionally elementary and can be found in texts such as Dixon and Massey (1983), Zar (1999) or Vanzolini (1993).

In the text and tables the following statistical conventions are followed:

$\mathrm{N}$, observations in sample

$\mathrm{R}, \mathrm{R}(\mathrm{x}), \mathrm{R}(\mathrm{y})$, ranges of the variables

$\mathrm{m}$, mean \pm its standard deviation

$\mathrm{s}$, sample standard deviation

$\mathrm{V}$, coefficient of variation

$b$, coefficient of regression \pm its standard deviation

a, regression constant \pm its standard deviation

$\mathrm{F}$, quotient of the variance due to regression by the

error (significance of the regression)

df, degrees of freedom $\mathrm{r}^{2}$, coefficent of determination

ns, not significant at the $5 \%$ level

$*$, significant at the $5 \%$ level

**, significant at the $1 \%$ level

***, significant at the $0.1 \%$ level.

Geography is extremely important in this context; in the text I do not enter in details about the localities, but there is a Gazetteer at the end.

\section{RESULTS: PODOCNEMIS EXPANSA}

\section{Clutch Size}

P. expansa was described by Schweigger in 1812 . The first information on its breeding habits dates from Spix (1824: 2). In the description of Emys amazonica, a synonym, Spix mentions that it occurred in the rivers Solimões, Branco and Javarí and remarks, very much to the point: "In November it investigates, in groups, sandy islands, deposits 130 eggs in holes three feet deep, tramples down the sand with the breast; the young emerge from the sand in two weeks" (my translation). The mention of November as the month of reproduction indicates that Spix saw it at Ajaratuba, on the Rio Solimões, near the mouth of the Rio Purus (Vanzolini 1981: xv).

Since then $P$. expansa has been repeatedly and extensively mentioned in the literature. However, the needed set of data for the proper study of reproductive strategies - good samples of females from a single locality, at the same time, measured and weighed, and the respective clutches counted and weighed - does not exist. The available data are of two sorts: anecdotal, such as Spix's above, with which I shall not deal, and references to (usually aggregate) numbers of nests (alternatively of females found nesting), and of eggs, laid, hatched and failed. Of these data I try to make the best use, complementing, whenever possible, the statistical treatment.

Mosqueira-Manso (1945) is the first author to present actual data on the reproduction of $P$. expansa at the famous beach of Pararuma, on the Orinoco, cited since the days of Humboldt. He reports (Table II, this paper) 3172 eggs from 35 excavated nests, averaging 90.6 eggs/clutch. 
Blohm and Fernández-Yépez (1948: 45) say, also from personal experience at Pararuma, that clutches may reach 150 eggs, but usually contain 85 to 90 . Later in the same paper they state that findings of up to 125 eggs are rare, and place the average at 75 .

Ramirez-E. (1956) has a very valuable paper on the same area of the Orinoco. He has data, for 7 consecutive years (1950 to 1956), for four beaches spread along some $80 \mathrm{~km}$ of river: Pararuma, Playa del Medio, Playa Blanca and Cabullarito. $\mathrm{He}$ presents for each beach and year the number ("calculo aproximado", Cuadro Nr. 3, p. 53) of "Tortugas ponedoras" (laying turtles) and of "Huevos puestos" (eggs laid). The number of samples (years), 5 to 7, available for each beach and the broad ranges of the variables make this a favourable case for regression analysis. This was performed and the results are (Table I, Fig. 1):

\section{All regressions are linear.}

2. The fits are unusually good. In many years of using statistical methods in zoological research I have never seen such high levels of significance ("calculo aproximado" indeed).

3. The four localities agree closely among themselves, and the joint regression is precisely as good as the individual ones.

4. In all cases the intercept (the regression constant, a) does not differ significantly from zero; consequently the regression equation $y^{\prime}=a+$ $b x$ reduces to $y^{\prime}=b x$, and $b=y^{\prime} / x-$ the slope, or coefficient of regression, i.e., the increase in the dependent variable consequent to an increase of one unit in the independent variable, actually estimates the average clutch size. In this case we have 75 eggs.

Roze (1964) says, about the same Orinoco beaches, that the number of eggs is variable, 150 in one nest being a record, and 82-86 the average.

Valle et al. (1973: VIII-E 75) report, for another traditional beach, Taboleiro Leonardo, on the
Rio Trombetas, also well-known in the literature, a range of 56-136, and an average of 75 eggs per nest.

Brito (1978) has counts of eggs per nest, fertile and unfertile, in three beaches of the middle Rio Purus, a tributary of the Solimões on its right bank: Aramiã, Axioma and Mapiciarí. His data show a very broad spread (Table II). The three beaches are heterogeneous in clutch size: Axioma agrees with Aramiã and both differ from Mapiciarí. The approximate distance between the beaches, going downriver are: Aramiã-Axioma 145 km, Axioma-Mapiciarí $39 \mathrm{~km}$.

Correa (1978) has tables of the number of laying females and of eggs laid in 6 beaches in the Rio Branco (Mandulão, Anta, Gaivota, Aricurá, Pacheco and Santa Fé) and in 8 beaches on the Rio Juruá (Joanico do Pato, Floresta, Harmonia, Santa Helena, Nova Olinda, Onça, Reforma and São Sebastião). Within each riverbasin clutch sizes may be shown graphically to be homogeneous (they stand on a straight line), so it is possible to do a regression analysis (Table I). The results are closely analogous to those of Ramirez-E. (1956).

Vecchi (1978), a newspaperman, visited Taboleiro Leonardo during a research campaign by the Brazilian federal conservation agency. He was given, and published in a magazine feature, data on clutch size for the seasons 1976-1977 and 1978 (Table II). The data differ at the $5 \%$ level, showing lack of homogeneity in time: in fact in consecutive years.

Alho and Padua (1982) have data on 393 females nesting on Taboleiro Leonardo. I do not fully understand their statistical treatment, but two kinds of data can be extracted from the paper. In their Table I it is seen that clutch size varied from 63 to 134 , with average $91.50 \pm 1.15$ eggs (standard deviation calculated by myself). Their Table III, however, permits a regression analysis, such as performed with the data of Ramirez-E. (1956) and Correa (1978). The regression is linear, with an exceedingly good fit; the intercept does not differ significantly from zero and the slope (average clutch) is 98.9. 
TABLE I

Podocnemis expansa, regression of the number of eggs on the number of females or nests.

\begin{tabular}{|c|c|c|c|c|c|c|}
\hline $\mathrm{N}$ & $\mathrm{R}(\mathrm{x})$ & $\mathrm{R}(\mathrm{y})$ & $\mathrm{b}$ & $\mathrm{a}$ & $\mathrm{F}$ & $\mathrm{r}^{2}$ \\
\hline \multicolumn{7}{|l|}{ Ramirez-E. 1956} \\
\hline $\begin{array}{c}\text { Pararuma } \\
5 \\
\end{array}$ & 2905-10500 & $217875-772500$ & $73.5 \pm 0.90$ & $6790 \pm 102973 \mathrm{~ns}$ & $6674.7 * * *$ & 0.9996 \\
\hline $\begin{array}{c}\text { Playa del Medio } \\
7\end{array}$ & $4930-26200$ & $69750-1965000$ & $75.0 \pm 0.03$ & $111 \pm 208456 \mathrm{~ns}$ & $4641350 * * *$ & 0.99999 \\
\hline $\begin{array}{c}\text { Playa Blanca } \\
6\end{array}$ & $85-7700$ & $6375-577500$ & $75.0 \pm 0.02$ & $-0.02 \pm 82147 \mathrm{~ns}$ & $9885063 * * *$ & 0.9885 \\
\hline $\begin{array}{c}\text { Cabullarito } \\
6\end{array}$ & $1200-7520$ & $90000-564000$ & 75.0 & 0 & & 1 \\
\hline $\begin{array}{c}\text { All beaches } \\
24\end{array}$ & $85-26200$ & $6375-196500$ & $75.0 \pm 0.08$ & $479 \pm 133162 \mathrm{~ns}$ & $968685 * * *$ & 0.99998 \\
\hline \multicolumn{7}{|l|}{ Correa 1978} \\
\hline $\begin{array}{c}\text { Rio Branco } \\
5\end{array}$ & $9-157$ & $838-15447$ & $98.3 \pm 0.98$ & $69.2 \pm 2276 \mathrm{~ns}$ & $10123 * * *$ & 0.9996 \\
\hline $\begin{array}{c}\text { Rio Juruá } \\
5\end{array}$ & $21-141$ & $2136-16888$ & $122.6 \pm 7.22$ & $-283.8 \pm 2765.2 \mathrm{~ns}$ & $288.4 * * *$ & 0.98979 \\
\hline \multicolumn{7}{|c|}{ Alho \& Padua 1982} \\
\hline 24 & $15-475$ & $1365-44664$ & $98.9 \pm 1.53$ & $-1317.6 \pm 2778.7 \mathrm{~ns}$ & $4169.2 * * *$ & 0.9948 \\
\hline
\end{tabular}

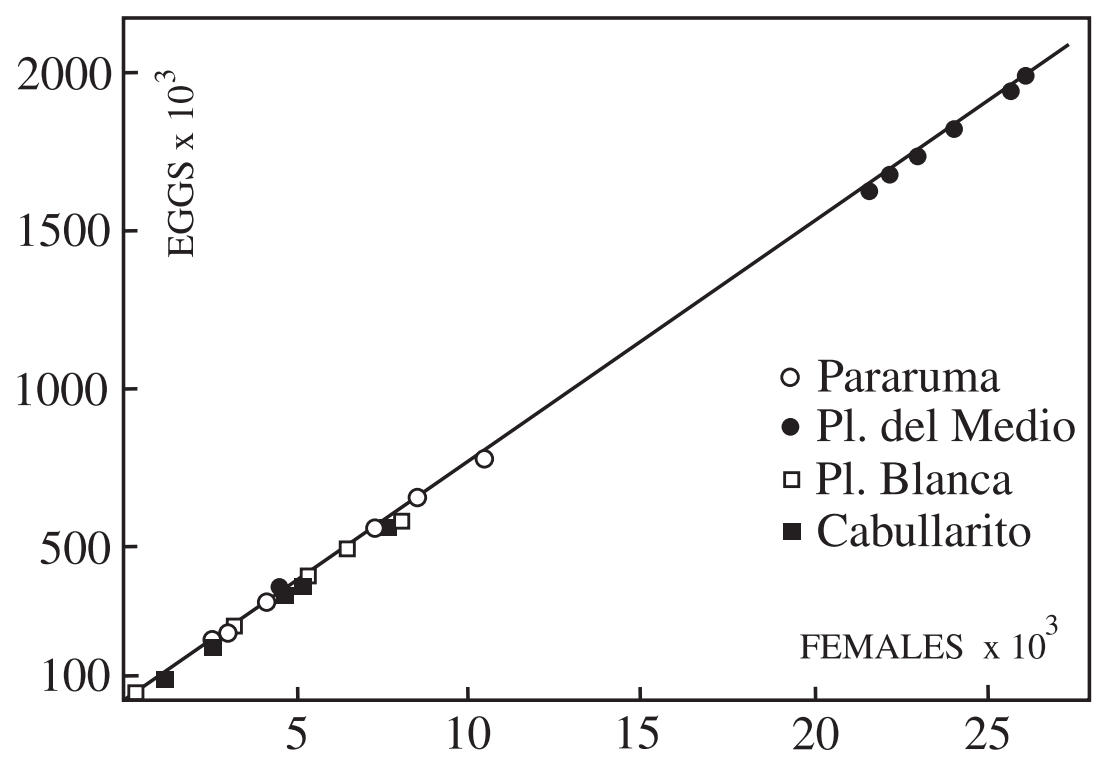

Fig. 1 - Podocnemis expansa. Regression of the number of eggs laid on the number of laying females, beaches on the Rio Orinoco (data from Ramirez-E. 1956).

\section{Comments}

We have some scattered data that do not contain much information, but also seven excellent regression analyses from widely distributed localities.
Analysis of covariance shows that the slopes (which, it will be remembered, estimate the average clutch), are highly heterogeneous $(\mathrm{F}=40039$ for 6 and 44 degrees of freedom). Application of Tukey's test 


\section{TABLE II}

Podocnemis expansa, data on clutch size.

\begin{tabular}{l|l|r|r|r}
\hline Author & Beach & Nests & Eggs & Average \\
\hline Mosqueira-Manso 1945 & Pararuma & 35 & 3172 & 90.6 \\
\hline Brito 1978 & Aramiã & 327 & 35897 & 109.9 \\
& Axioma & 110 & 12727 & 115.7 \\
& Mapiciarí & 239 & 37886 & 158.5 \\
\hline Vecchi 1978 & Leonardo 1976-77 & 3167 & 265973 & 84.0 \\
& & 1978 & 133737 & 90.5 \\
\hline
\end{tabular}

TABLE III

P. expansa, clutch size, slope, Tukey's test.

\begin{tabular}{l|r}
\hline Sample & \multicolumn{1}{|c}{$\mathrm{b}$} \\
\hline 1. Pararuma & 73.5 \\
2. Playa del Medio & 75.0 \\
3. Playa Blanca & 75.0 \\
4. Cabullarito & 75.0 \\
5. Rio Branco & 98.3 \\
6. Leonardo & 98.9 \\
7. Juruá & 122.6 \\
\hline
\end{tabular}

(Table III) makes excellent geographic sense:

1. The four Orinoco samples cluster tightly at 75 eggs/clutch, in agreement with Blohm and Fernández-Yépez (1948), not with MosqueiraManso (1945).

2. The Trombetas and Rio Branco samples agree closely at nearly 100 eggs/clutch.

3. The Juruá sample stands out at 122 eggs/clutch; the geographically close Purus samples (Table II) also have high numbers.

\section{Hatching Success}

It is safe to assume that no clutch will ever have a perfect hatching success. Mortality in the nest is unavoidable due to causes of three kinds: (i) intrinsic to the eggs (failure of fertilization or divers types of lack of viability); (ii) nest predation and (iii) drowning.
P. expansa nests during the low water season and hatches as the rivers begin to rise. Any premature rise of the river will result in a concomitant rise of the water table and flooding of the deeper layers of the nest. This has been witnessed many times. The clutches on which we have data were all protected against predators, so the causes of mortality must have been intrinsic or due to nest flooding.

The data available in the literature consist essentially of counts of excavated nests, specifying the number of young, live and dead, and of addled eggs. The quotient of the number of live young by the total sum is the hatching success.

Valle et al. (1973) have data on the hatching success of $P$. expansa at Taboleiro Leonardo for the seasons of 1965, 1966 and 1970-1972, for the beach at Monte Cristo, Rio Tapajós, for 1971 and 1972), and for the beach at Rolino, also in the Tapajós, for 1972. Table IV shows clearly that the years 1970 and 1971 were clearly anomalous, with very low survival rates; this is probably due to early rises of the Trombetas. As it was done in the case of clutch size, I tested graphically, on a scatter diagram, the presence of regression of the number of viable young against the number of eggs laid, excluding, the abnormal years. The regressions proved, as in the case of clutch size, to pass through the origin and to have extremely high coefficients of determination (Table V).

The data of Brito (1978) and Correa (1978) are amenable to the same type of analysis (Table V). Analysis of covariance showed all samples to be ho- 


\section{TABLE IV}

Podocnemis expansa, data on hatching success.

\begin{tabular}{|c|c|c|c|c|}
\hline \multirow[t]{2}{*}{ Author } & \multirow[t]{2}{*}{ Beach } & \multicolumn{2}{|c|}{ Eggs } & \multirow[b]{2}{*}{ Success } \\
\hline & & Laid & Hatched & \\
\hline Mosqueira-Manso 1945 & Pararuma & 3172 & 2878 & 0.91 \\
\hline \multirow[t]{8}{*}{ Valle, Alfinito \& Silva 1973} & Leonardo 1965 & 397500 & 300000 & 0.75 \\
\hline & 1966 & 540000 & 472500 & 0.89 \\
\hline & 1970 & 225000 & 45000 & $0.20 \leftarrow$ \\
\hline & 1971 & 236250 & 68748 & $0.29 \leftarrow$ \\
\hline & 1972 & 126308 & 98773 & 0.78 \\
\hline & Monte Cristo 1971 & 10836 & 8765 & 0.73 \\
\hline & 1972 & 18293 & 13390 & 0.73 \\
\hline & Rolino & 492 & 342 & 0.70 \\
\hline \multirow[t]{3}{*}{ Brito 1978} & Aramiã & 35897 & 33522 & 0.93 \\
\hline & Axioma & 12727 & 10030 & 0.79 \\
\hline & Mapiciarí & 37886 & 31189 & 0.82 \\
\hline Vecchi 1978 & Leonardo & 251261 & 218338 & 0.87 \\
\hline Licata \& Elguezabal 1997 & Refúgio Arrau & & & 0.82 \\
\hline Naturatins 2001 & Lajeado & 1719 & 400 & 0.56 \\
\hline
\end{tabular}

TABLE V

Podocnemis expansa, regression of the number of live young on the number of eggs laid.

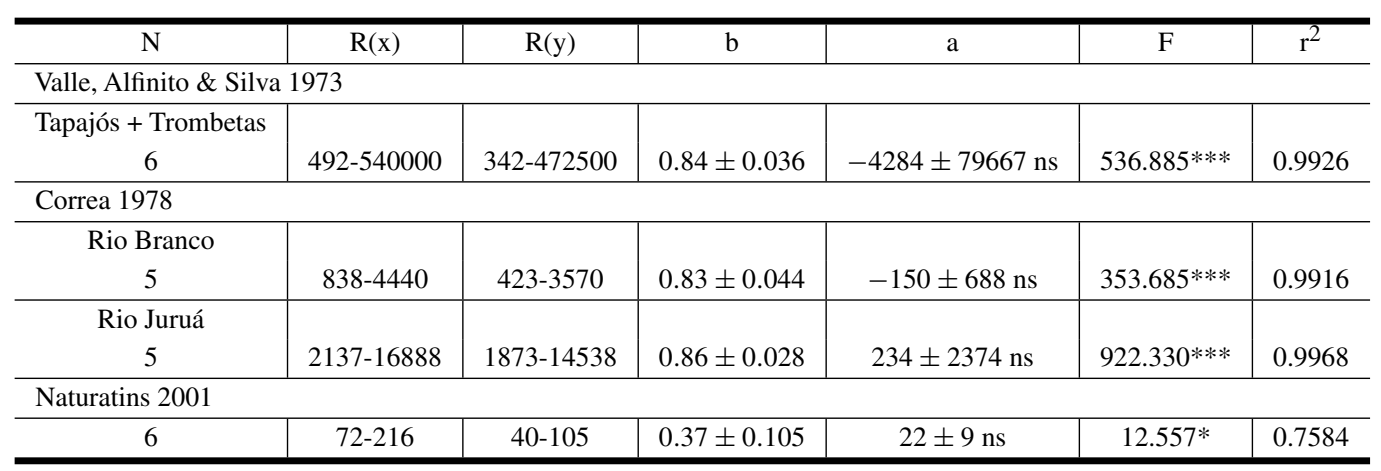

mogeneous $(\mathrm{F}<0.00015)$; the joint regression has a coefficient of determination of 0.9926 , and a coefficient of regression (average success) of 0.83 . This is in agreement with the hatching success of $85.98 \pm$ $1.066 \%$ quoted by Alho and Padua (1982) for the beach at Leonardo and of $81.7 \%$ cited by Licata and Elguezabal (1997) for the Orinoco (Wildlife Refuge of the Arrau Turtle). It is less than the rate of ca. $95 \%$ cited (without further documentation) by Alho et al. (1979) for Leonardo.
Finally, Naturatins, the conservation agency of the state of Tocantins, is currently conducting a management program of $P$. expansa and $P$. unifilis in the area of influence of the hydroelectric plant at Lajeado, on the Rio Tocantins, one of the major rivers of Central Brazil. They have published (Naturatins 2001) very interesting data on the hatching success of eggs from transplanted nests of both species. It is obvious that these data cannot be directly compared with those obtained in more natural conditions, but 
such a comparison is useful in estimating the success of the management policies. Tables IV and V indicate that hatching success of $P$. expansa under management is lower than in the other cases studied. When I first became aware of this I contacted the colleagues at Naturatins: they had already noticed the fact and were taking steps. This fully validates the use of these prospected data in the orientation of conservation practices.

\section{Comments}

We have thus geographically variable clutch sizes and a practically fixed hatching success in the absence of predation. An extremely interesting, and to me unexpected, angle is the presence of uniformly high coefficients of determination, especially in what regards clutch size, with differences of close to $50 \%$ in number between river drainages and practically perfect correlations within any given drainage. This to me means that very severe selective pressures are at work, and explains the cases of geographical differentiation found. This can only be understood in the light of optimization theory: what is the most efficient investment a female can make in reproduction. I'll return to this.

\section{RESULTS: PODOCNEMIS UNIFILIS}

\section{Clutch Size (Tables VI and VII)}

Coutinho (1868) is the first author to mention clutches of $P$. unifilis. Based on his extensive experience in Amazonia, and without citing definite localities, he states that clutches vary from 25 to 30 eggs.

The next author is Mondolfi (1955), who studied turtles on the upper Orinoco valley (rivers $\mathrm{Cu}$ naviche and Capanaparo). He cites three nests, with 22, 24 and 28 eggs, and three autopsied females, with 14,18 and 18. The difference between the two sets, small as they are, is statistically significant, and the data are better abandoned.

Medem (1960) cites four nests from the upperRio Caquetá, Colombian Amazonian, with 18-24 eggs (no further details). Medem (1964) had counts from 13 nests from the lower Rio Ariari, Colombian Amazonia. In 1969 Medem published on 24 nests from Isla Vieja, upper Rio Caquetá. His two sets of data are incompatible $(\mathrm{t}=7.782 * * *, 51 \mathrm{df})$. It is not probable that the difference be due to predation, which would have to have been very selective. These data are better not taken into consideration for the time being.

I (Vanzolini 1977 b) presented data on P. unifilis clutch size from the rivers Negro (Carvoeiro, Marová), Trombetas (Lago Jacaré) and Amazonas (Furo do Aiaiá). The samples (very small) do not show heterogeneity; the joint data are presented on Table VI. My archival data permit computation of the regression of clutch size on plastral length of the females; the fit is not ideal, but the presence of correlation is unmistakable.

Foote (1978) has a table on clutches from the area around Leticia and from the lower Putumayo (cited jointly), from which it is possible to compute the statistics for a sample of nests (Table VI).

Correa (1978) has data from the Rio Juruá, amenable to regression analysis (Table VII). As in the case of $P$. expansa treated above, the intercept does not differ significantly from zero and thus the slope estimates the mean clutch, in the case 25 . The coefficient of determination, as in the case of $P$. expansa, is very high (0.9854), which again speaks for very strong selective pressures. Correa (l.c.) also mentions a total of 1469 eggs from 59 females from the Rio Purus - a mean of $24.9 \pm 1.13$, in close agreement with the Juruá sample.

Fachin (1982), in a thorough monograph on $P$. unifilis in the Iquitos area, presents data on 53 nests. Soini (1983) has two sets of data from the same Iquitos region. One, which I here shall call (a), consists of a distribution of frequencies of eggs in 7 nests, from which statistics can be computed straightforwards. The other, (b), is a table ("Cuadro 2") with clutch size statistics for the months of July, August and September-October of 1979 through 1982. This table affords some very interesting recalculations. It is possible to perform an analysis of variance, that shows the samples to be thoroughly homogeneous 


\section{TABLE VI}

Podocnemis expansa, data on clutch size.

\begin{tabular}{|c|c|c|c|c|c|}
\hline Author & $\mathrm{N}$ & $\mathrm{R}$ & $\mathrm{m}$ & $\mathrm{s}$ & $\mathrm{V}$ \\
\hline Mondolfi 1955 (nests) & 4 & $22-28$ & $24.0 \pm 1.41$ & 2.8 & 11.8 \\
\hline (females) & 3 & $14-18$ & $16.7 \pm 1.33$ & 2.3 & 13.9 \\
\hline Medem 1964 & 13 & $20-27$ & $23.2 \pm 0.61$ & 2.2 & 9.5 \\
\hline 1969 & 40 & $5-24$ & $13.1 \pm 0.70$ & 4.5 & 34.2 \\
\hline Vanzolini $1977 b$ & 10 & $16-33$ & $24.4 \pm 1.63$ & 5.1 & 21.1 \\
\hline Foote 1978 & 12 & $22-41$ & $27.3 \pm 1.65$ & 5.7 & 20.9 \\
\hline Fachin 1982 & 53 & $22-43$ & $31.1 \pm 0.63$ & 4.6 & 14.8 \\
\hline Soini 1983(a) & 7 & $18-33$ & $26.4 \pm 2.34$ & 6.2 & 23.4 \\
\hline 1983(b): viii.1979 & 52 & & $31.7 \pm 0.97$ & & \\
\hline ix-x.1979 & 3 & & $29.3 \pm 2.67$ & & \\
\hline vii.1980 & 68 & & $35.2 \pm 0.81$ & & \\
\hline viii. 1980 & 86 & & $33.8 \pm 0.71$ & & \\
\hline ix-x.1980 & 7 & & $26.3 \pm 2.34$ & & \\
\hline vii.1982 & 33 & & $37.0 \pm 1.07$ & & \\
\hline viii.1982 & 70 & & $33.9 \pm 0.84$ & & \\
\hline ix-x.1982 & 19 & & $33.3 \pm 1.12$ & & \\
\hline Pritchard \& Trebbau 1984 & 5 & $19-35$ & 24.4 & & \\
\hline Thorbjarnarson et al. 1993 & 22 & $14-31$ & $23.3 \pm 0.98$ & 4.6 & 19.7 \\
\hline Souza \& Vogt 1994 & 46 & & $23.7 \pm 0.69$ & 4.7 & 19.6 \\
\hline
\end{tabular}

TABLE VII

Podocnemis unifilis, regressions.

\begin{tabular}{|c|c|c|c|c|c|c|}
\hline $\mathrm{N}$ & $\mathrm{R}(\mathrm{x})$ & $\mathrm{R}(\mathrm{y})$ & $\mathrm{b}$ & $\mathrm{a}$ & $\mathrm{F}$ & $\mathrm{r}^{2}$ \\
\hline \multicolumn{7}{|c|}{ Number of eggs on number of females (Correa 1978) } \\
\hline 5 & $161-1336$ & $4772-34075$ & $25.0 \pm 1.76$ & $1495 \pm 5035 \mathrm{~ns}$ & $202.140 * * *$ & 0.9854 \\
\hline \multicolumn{7}{|c|}{ Number of live young on number of eggs } \\
\hline $\begin{array}{c}\text { Medem } 1969 \\
15 \\
\end{array}$ & $9-24$ & $8-22$ & $0.92 \pm 0.094$ & $-1.123 \pm 1.0833 \mathrm{~ns}$ & $96.073^{* * *}$ & 0.8808 \\
\hline $\begin{array}{c}\text { Correa 1978, Rio Juruá } \\
5 \\
\end{array}$ & $4772-34075$ & $4421-31842$ & $0.93 \pm 0.017$ & $155 \pm 4677 \mathrm{~ns}$ & $2747.228 * * *$ & 0.9989 \\
\hline $\begin{array}{c}\text { Fachin } 1982 \\
12 \\
\end{array}$ & $29-40$ & $28-35$ & $0.64 \pm 0.087$ & $11.0 \pm 0.82 * * *$ & $53.734 * * *$ & 0.8431 \\
\hline $\begin{array}{c}\text { Naturatins } 2001 \\
21 \\
\end{array}$ & $2-304$ & $1-280$ & $0.88 \pm 0.039$ & $-3.3 \pm 15.48 \mathrm{~ns}$ & $513.601 * * *$ & 0.9643 \\
\hline \multicolumn{7}{|c|}{ Number of eggs on plastral length (Vanzolini 1977b) } \\
\hline 10 & $293-409$ & $17-33$ & $0.13 \pm 0.028$ & $-20.6 \pm 1.71 * * *$ & $22.061 * *$ & 0.7739 \\
\hline
\end{tabular}

$(\mathrm{F}=0.757$ for 8 and $337 \mathrm{df})$. They agree also, and closely, with Fachin's (1982) data. The data for the Iquitos area are very solid indeed. (Fachin (1993) used again his 1982 data, with no novelties in the analysis).
Pritchard and Trebbau (1984) have data for 5 nests in the Rio Cinaruco, Venzuelan Orinoquia, and Thorbjarnarson et al. (1993) have data on the Rio Capanaparo, another Orinoco tributary. Souza and Vogt (1994) have data on the Rio Guaporé, State of 
Rondonia, Brazil (Table VI).

Looking at the geographic picture, it is seen that the coverage is ample. The Iquitos area stands out, with a large and homogeneous set of samples, with a range of at least 22-43 and a mean of 34.2 eggs per clutch. All other samples agree among themselves, with means varying from 23 to 27 eggs per clutch.

\section{HATCHING SuCCESS}

Medem (1969) has extensive data from Isla Vieja, Rio Caquetá. Plotting his number of young vs number of eggs shows that his materials can be separated in two groups: one with disastrous results (survival of 1-2 eggs), the other with better results, falling on a straight line, whose statistics are shown on Table VII.

Correa (1978) has summary data for the Rio Purus (Table VIII) and sets for 5 beaches on the Rio Juruá (Pupunha, Pato, Reforma, Joanico Central and São Sebastião), which are amenable to regression analysis (Table VII).

Fachin (1982) has a very heterogeneous set of data for the Iquitos area. I culled out the obviously divergent data, and did regression analysis on the remainder (Table VII). The regression does not pass through the origin, so it is not comparable with those so far seen. I present these data for the sake of completeness, but show also (Table VIII) the bulk rate. Finally, Soini (1983) has data for the Iquitos area (Table VIII).

\section{TABLE VIII}

Podocnemis unifilis, hatching success.

\begin{tabular}{c|c|c|c}
\hline Author & Eggs & Young & Rate \\
\hline Correa 1978, Rio Purus & 1469 & 1430 & $0.973 \pm 0.0042$ \\
Soini 1983 & 1206 & 944 & $0.783 \pm 0.0119$ \\
Fachin 1982 & 399 & 377 & $0.970 \pm 0.0061$ \\
\hline
\end{tabular}

As mentioned for $P$. expansa, Naturatins has published data on the hatching success of transplanted nests of $P$. unifilis on the Tocantins (Table VII). It is seen that the regression of young hatched alive on the number of eggs laid is excellent $\left(r^{2}=0.9643\right)$, passes through the origin, and that the survival rate, $88 \%$ is normal for the species. This is a very successful management program.

\section{Comments}

Looking at the ensemble of the data, it is seen that, out of five sets of data analyzed, success is above $90 \%$ in four, a little below $80 \%$ in one. The distributions of frequencies of Soini (1983) and Fachin (1982) for the Iquitos area differ statistically $\left(\chi^{2}=\right.$ 6.597 for $1 \mathrm{df}$ ). The latter agrees with the ensemble of the data and of course should be preferred.

\section{DISCUSSION}

\section{GEOGRAPHic DifFERENTIATION}

A striking fact, noticeable for both species, is the very limited variability of clutch size, indicating strong selective control. This goes hand in hand with geographical variation in the clutch size of $P$. expansa, and, to a somewhat lesser degree, of $P$. uniflis.

Geographic variation in P. expansa had ben previously found by Sites et al. (1999), who studied microsatellite markers from seven beaches on the Rio Araguaia (Gaivota, Cascalho, Três Furos, Volta Grande, Rebojinho, Barreira Branca and Fazenda Montaria) and from one beach on the Rio Tapajós, near Santarém. They found homogeneity among the Araguaia samples, but sharp differences between this and the Tapajós materials.

Valenzuela (2001) also studied geographic variation in microsatellite markers of $P$. expansa, in four beaches on the Rio Caquetá (Centro, Guadual, Yarumal and Tamanco), spread along some $100 \mathrm{~km}$ of river; she further compared the Caquetá turtles with those from the Araguaia, using materials from the study of Sites et al. (1999). She found the expected differences between the two river basins, but also, unexpectedly, within the Caquetá. This is plausibly explainable in terms of the fidelity of the turtles to their taboleiros, where, moreover, they copulate gregariously immediately after laying.

However, I also found geographic differentia- 


\section{TABLE IX}

Podocnemis. Statistics of the distributions of frequencies of egg volume.

\begin{tabular}{|c|c|c|c|c|c|c|}
\hline Sample & Locality & $\mathrm{N}$ & $\mathrm{R}$ & $\mathrm{m}$ & $\mathrm{s}$ & V \\
\hline \multicolumn{7}{|l|}{ P. unifilis } \\
\hline Mondolfi 1955 & Apure & 5 & $21.9-24.2$ & $22.80 \pm 0.398$ & 0.86 & 3.8 \\
\hline Foote $1978 *$ & Leticia, Içá & & & 20.09 & & \\
\hline Fachin $1982 *$ & Samiria & & & 19.94 & & \\
\hline MZUSP 2890 & Fonteboa & 35 & 09.8-19.8 & $14.93 \pm 0.380$ & 2.24 & 15.1 \\
\hline 2880 & Coarí & 18 & $14.2-20.7$ & $15.90 \pm 0.354$ & 1.50 & 9.5 \\
\hline 2881 & $"$ & 6 & $10.3-12.4$ & $11.65 \pm 0.317$ & 0.78 & 6.7 \\
\hline 2506 & Trombetas & 12 & $22.6-26.2$ & $24.32 \pm 0.347$ & 1.20 & 4.9 \\
\hline 2510 & $"$ & 17 & $14.4-17.3$ & $15.59 \pm 0.177$ & 0.73 & 4.7 \\
\hline 2511 & $"$ & 16 & $15.2-21.7$ & $19.38 \pm 0.377$ & 1.51 & 7.8 \\
\hline 2708 & " & 11 & $27.4-29.7$ & $28.50 \pm 0.221$ & 0.71 & 2.6 \\
\hline 2874 & $"$ & 10 & $14.7-18.5$ & $16.09 \pm 0.443$ & 1.40 & 8.7 \\
\hline 2891 & $"$ & 13 & $13.7-17.7$ & $14.90 \pm 0.295$ & 1.06 & 7.1 \\
\hline 2892 & $"$ & 19 & $14.9-18.9$ & $16.37 \pm 0.269$ & 1.17 & 7.2 \\
\hline 4014 & Araguaia & 23 & $19.4-23.6$ & $21.27 \pm 0.246$ & 1.18 & 5.6 \\
\hline \multicolumn{7}{|l|}{ P. expansa } \\
\hline MZUSP 2870 & Trombetas & 4 & $30.2-40.6$ & $35.05 \pm 2.142$ & 4.28 & 12.2 \\
\hline 2871 & " & 5 & $25.8-30.2$ & $26.80 \pm 1.012$ & 2.66 & 8.4 \\
\hline
\end{tabular}

tion in clutch size and hatching success in $P$. unifilis, which is not known to be faithful to particular beaches, or to have herd behavior. There have been no genetic studies of this species.

\section{Optimal EgG-SIZE TheOrY}

The strict control of clutch size leads us into optimal egg size theory (OES), which opposes size of offspring to size of clutch: "offspring size is usually less variable than offspring number"... "a wellfounded assumption of these [OES] models" (Rowe 1994: 35). Or else: "they all agree with OES that fluctuation in resources for reproduction should affect clutch size, whereas egg size within a female should remain relatively constant" (Roosenburg and Dunham 1997: 290). Or, still: "...a major prediction from OES theory is that, within a population, the amount of variation in reproductive output among females should result primarily from variation in the number of osffspring produced and secondarily from variation in egg size" (Congdon 1989: 367).

Reliable estimates of egg volume can be indirectly obtained from measurements of egg diameters (Vanzolini 2001). We have in the Museum collection eleven samples $\mathrm{f} P$. unifilis eggs from a variety of Brazilian localities. In the literature, Mondolfi (1955) has measurements of 5 eggs. Fachin (1982: Table V) has a table containing average diameters of eggs from the Rio Samiria. Analogous data can be read from Foote's (1978) Figure 3. (Volumes calculated from diameter averages coincide within $1 \%$ with volumes analytically determined. It goes without saying that no estimates of variance can be obtained, but the visual comparisons are nevertheless valuable). All the data available are shown on Table IX, where are also included the data for two samples of $P$. expansa eggs, collected by myself at the Taboleiro Leonardo, Rio Trombetas. They were 


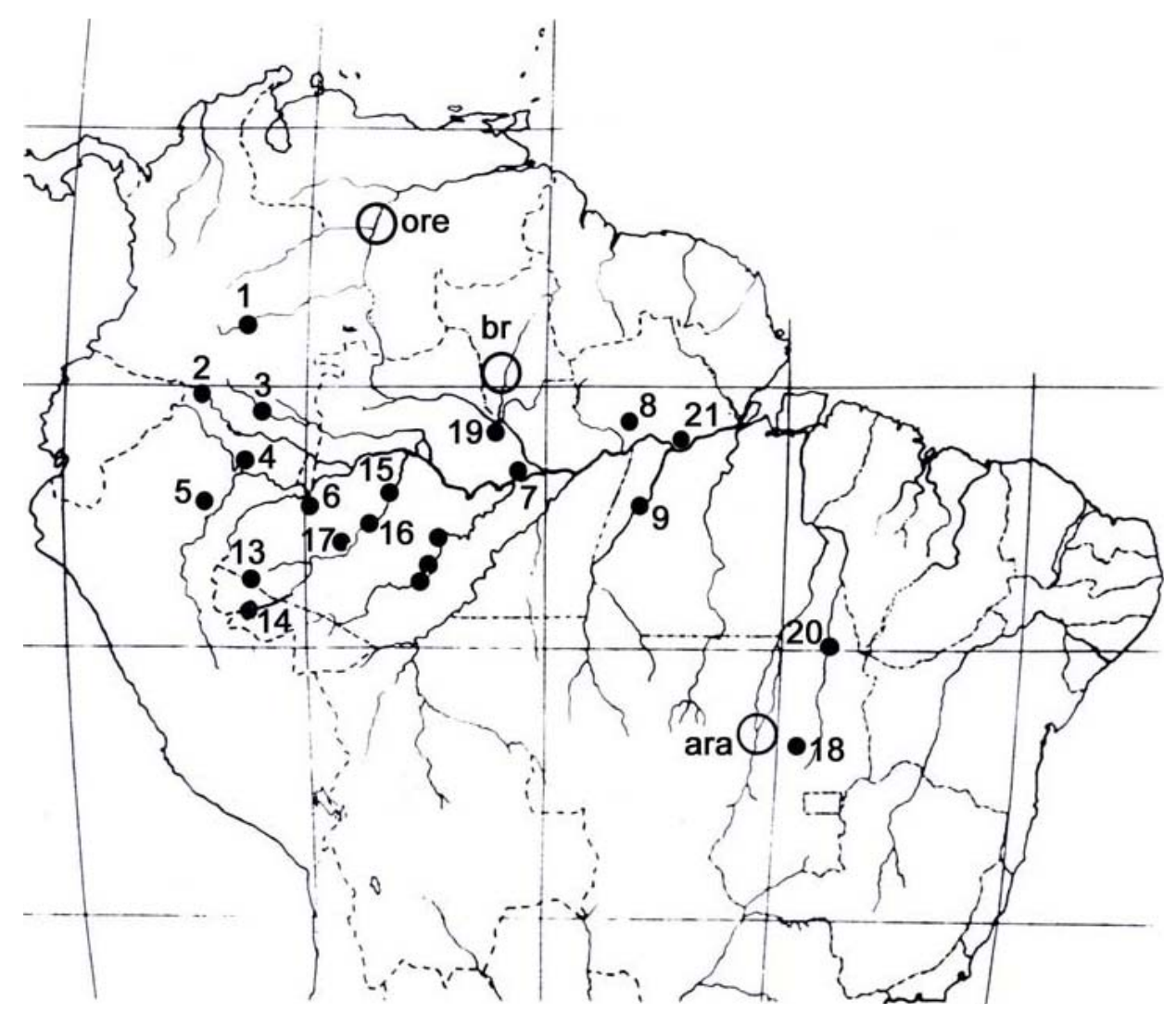

Fig. 2 - Beaches mentioned. 1, Rio Ariari. 2, Isla Vieja. 3, Rio Caquetá (Centro; Guadual; Tamanco; Yarumal). 4, Iquitos. 5, Rio Samiria. 6, Leticia. 7, Ajaratuba. 8, Rio Trombetas (Lago Jacaré; Taboleiro Leonardo). 9, Rio Tapajós (Monte Cristo; Rolino). 10, Rio Purus (Pato; Joanico Central; Joanico do Pato; Joanico Central). 11, Rio Juruá (Pupunha; Harmonia). 12, Rio Juruá (Onça; São Sebastião). 13, Rio Juruá (Floresta). 14, Rio Juruá (Reforma). 15, Rio Purus (Aramiã). 16, Rio Purus (Axioma). 17, Rio Purus (Mapiciarí). 18, Barreira Branca. 19, Rio Negro (Carvoeiro; Marová). 20. Rio Tocantins (Lajeado). ARA, Rio Araguaia (Rebojinho; Volta Grande; Ilha do Cascalho; Três Furos; Gaivota; Fazenda Montaria). BR, Rio Branco (Ilha Aicurá; Anta; Mandulão; Pacheco; Santa Fé). ORE, Rio Orinoco, Pararuma region (Cabullarito; Rio Arauca; Rio Cunaviche; Playa Blanca; Rio Capanaparo; Rio Cinaruco; Playa del Medio; Refugio de la Tortuga Arrau; Pararuma).

freshly laid eggs unearthed by subsequent females.

Simple inspection of Table IX shows much variation in egg volume. Analysis of variance for the 7 samples from the Trombetas (a compass of 120 $\mathrm{km})$ afforded a value of $\mathrm{F}=248.517 * * *$ for 6 and 91 d.f. Analysis of variance including all available materials also affords a high value of $\mathrm{F}\left(130,535^{* * *}\right.$, 11 and 173 d.f.), but Tukey's test reveals no regularities - it rather stresses the extreme and uneven, patternless, character of the variation.
The only two samples of $P$. expansa eggs available, already laid, collected within meters and minutes of each other, differ significantly $\left(\mathrm{t}=3.744^{* *}\right.$, 7 d.f.) in volume.

The present data were prospected, not obtained from planned and orderly executed research. Even so, they permit to say that these two large species of river turtles fail to obey an important pattern predicted by optimal egg-size theory.

Criticism has been raised against the applica- 


\section{GAZETTEER}

Latitudes South and longitudes West taken for granted. l.b. = left bank; r.b. = right bank.

Aiaiá, Furo, enters the Rio Amazonas (r.b.) at 0230, 5420.

Aicurá, Ilha (Rio Branco), 0034 N, 6137.

Ajaratuba (Rio Amazonas), 0337, 6112.

Anta (Rio Branco), 0035 N, 6147.

Aramiã (also Arimã) (Rio Purus), 0547, 6358.

Arauca, Rio, enters the Rio Orinoco (l.b.) at 0724 N, 6635

Ariari, Rio, enters the Rio Guaviare (1.b.) at 0235 N, 7247

Arrau, Refugio de la Tortuga (Rio Orinoco), between $0625 \mathrm{~N}$ and $0634 \mathrm{~N}$.

Axioma (Rio Purus), 0645, 6431.

Barreira Branca (Rio Crixás Açu), 1342, 4858.

Branco, Rio , enters the Rio Negro (1.b.) at 0124, 6151.

Cabullarito (Rio Orinoco), 0735 N, 6626.

Capanaparo, Rio, enters the Rio Orinoco (1.b.) at 0701 N, 6707.

Caquetá, Rio, enters the Rio Amazonas (1.b.), with the Brasilian name of Japurá, at 0308, 6446.

Carvoeiro (Rio Negro), 0126, 6201.

Cascalho, Ilha (Rio Araguaia), 1259, 5034.

Centro (Rio Caquetá), 0102, 7129.

Cinaruco, Rio, enters the Rio Orinoco (l.b.) at 0639 N, 6708.

Crixás Açu, Rio, enters the Rio Araguaia (r.b.) at 1319, 5036.

Cunaviche, Rio, enters the Rio Arauca (r.b.) at 0719 N, 6711.

Floresta (Rio Juruá), 0734, 7225.

Gaivota (Rio Branco), not located.

Gaivota (Rio Araguaia), 1306, 5036.

Guadual (Rio Caquetá), 0051, 7133.

Guaporé, Rio, enters the Rio Mamoré (r .b.) at 1154, 6501.

Guaviare, Rio, enters the Rio Orinoco (l.b.) at 0403 N, 6744.

Harmonia (Rio Juruá), 0535, 6736.

Iquitos (Rio Amazonas), 0347, 7313.

Jacaré, Lago (Rio Trombetas), 0118, 5647.

Joanico Central (Rio Juruá), 0352, 6623.

Joanico do Pato (Rio Juruá), 0352, 6623.

Juruá, Rio, enters the Rio Amazonas (r.b.) at 0237, 6550.

Lajeado (Rio Tocantins), 0945, 4821.

Leonardo, Taboleiro (Rio Trombetas), 0120, 5645.

Leticia (Rio Amazonas), 0409, 6957.

Madeira, Rio, enters the Rio Amazonas (r.b.) at 0322, 5845.

Mamoré, Rio, enters the Rio Madeira (r.b.) at 1024, 6563. 
Mandulão (Rio Branco), 0009 N, 6147.

Mapiciarí (Rio Purus), 0705, 6437.

Marová (Rio Negro), 0109, 6235.

Montaria, Fazenda (Rio Araguaia), 1322, 5041.

Monte Cristo (Rio Tapajós), 0404, 5539.

Negro, Rio, enters the Rio Amazonas (1.b.) at 0308, 5955.

Nova Olinda (Rio Juruá), 0412, 6627.

Onça (Rio Juruá), 0609, 6753.

Pacheco (Rio Branco), 0032 N, 6142.

Pararuma (Rio Orinoco), 0629 N, 6708.

Pato (Rio Juruá), 0350, 6621.

Playa Blanca (Rio Orinoco), 0711 N, 6658.

Playa del Medio (Rio Orinoco), 0630 N, 6706.

Pupunha (s) (Rio Juruá), 0506, 6710.

Purus, Rio, enters the Rio Amazonas (r.b.) at 0342, 6128.

Putumayo, Rio, enters the Rio Amazonas (1.b.), with the Brasilian name of Içá, at 0307, 6759.

Rebojinho (Rio Araguaia), 1246, 5042.

Reforma (Rio Juruá), 0828, 7252.

Rolino (Rio Tapajós), 0412, 5555.

Samiria, Rio, enters the Rio Marañon (r.b.) at 0442, 7413.

Santa Fé (Rio Branco), 0028 N, 6145.

Santa Helena (Rio Juruá), 0412, 6627.

São Sebastião (Rio Juruá), 0624, 6750.

Tamanco (Rio Caquetá), 0043, 7147.

Tapajós, Rio, enters the Rio Amazonas (r.b.) at 0224, 5441.

Três Furos (Rio Araguaia), 1300, 5034.

Trombetas, Rio, enters the Rio Amazonas (1.b.) at 0155, 5535.

Ucayali, Rio, enters the Rio Amazonas (r.b.) at 0430, 7327.

Vieja, Isla (Rio Caquetá), 0008, 7412.

Volta Grande (Rio Araguaia), 1249, 5037.

Yarumal (Rio Caquetá), 0056, 7135.

tion of optimization theory to turtle reproduction from another angle. Congdon and Gibbons (1987) show that, in two smaller North American emydids, pelvic structure constrains (and thus increases the variability of) egg size.

Of course, it is not to be hoped that field work on the reproduction of podocnemidid turtles will contribute much to OES, since the latter leans heavily on generalized models of competition theory (Smith and Fretwell 1974, Brockelman 1975) - a dimension signally lacking in podocnemidid research.

It seems to me that a laborious, but simple and 
rewarding field of research opens itself, emphasizing concomitant description and interpretation of reproductive strategies of podocnemidid turtles.

\section{ACKNOWLEDGMENTS}

Lee-Ann Hayek (United States National Museum) and Miguel Petrere Jr. (State University of S. Paulo at Rio Claro) provided much needed statistical support. W.R. Heyer (U.S. National Museum) and C.W. Myers (American Museum of Natural History) criticized an early version of the manuscript. Celso Morato de Carvalho (Federal University of Sergipe) helped to put the manuscript together. J.W. Gibbons helped with the literature. The Academy editorial staff has much helped cleaning up the manuscript. Our library staff has been outstanding in obtaining unusual, hard to find literature. This work has not been funded by any granting agency.

\section{RESUMO}

Dados sôbre tamanho da ninhada e viabilidade dos ovos foram colhidos na literatura para 7 praias tradicionalmente usadas por P. expansa para reprodução, e re-analisados por análise de regressão, do número de ovos sobre o número de fêmeas (ou de ninhos) e de filhotes sobre ovos postos. Todas as regressões foram lineares, passando pela origem, e com altíssimos coeficientes de determinação. O tamanho médio da ninhada variou de 75 a 123, e mostrou diferenciação geográfica: (i) Rio Orenoco, (ii) Rio Trombetas + Rio Branco e (iii) Rio Juruá + Rio Purus. A viabilidade média não mostrou diferenciação geográfica, ficando em cerca de $83 \%$. Em P. unifilis também houve diferenciação geográfica, as amostras da região de Iquitos tendo valores muito altos. A viabilidade média foi alta: apenas uma amostra, de Iquitos, teve sucesso inferior a 90\%. Os altos valores do coeficiente de determinação levam à consideração do volume dos ovos, que se revelou muito variável em ambas espécies, em contradição com idéias correntes sobre teoria do volume ótimo dos ovos.

Palavras-chave: reprodução de quelônios, viabilidade, tamanho da ninhada, teoria de tamanho ótimo do ovo, Podocnemis expansa, Podocnemis unifilis.

\section{REFERENCES}

AdLER K. (ed). 1981. Herpetology of Brazil, by JB vON SPIX AND J WAGLER. Facsimile reprint, Society for the Study of Amphibians and Reptiles. vii $+75+53$ +26 p., pls.

Alho CJR And Padua LFM. 1982. Reproductive parameters and nesting behavior of the Amazon turtle Podocnemis expansa (Testudinata: Pelomedusidae) in Brazil. Canad J Zool 60: 97-103.

Alho CJR, Carvalho AG and Padua LFM. 1979. Ecologia da tartaruga da Amazônia e avaliação do seu manejo na Reserva Biológica do Trombetas. Brasil Florestal 38: 29-47.

Blohm T and Fernandez-Yepez A. 1948. La Sociedad de Ciencias Naturales La Salle en Pararuma. Mem Soc Ci Nat La Salle, Caracas 8(21): 35-69.

BRITO WLS. 1978. Sobre a conservação de quelônios no Rio Purus. Bol Fund Brasil. Conserv Nat 13: 57-63.

Brockelman WY. 1975. Competition, the fitness of offspring and optimal clutch size. Amer Nat 109 (970): 677-699.

Congdon JD. 1989. Proximate and evolutionary constraints on energy relations of reptiles. Physiol Zool 62: $356-373$.

Congdon JD and GibBons JW. 1987. Morphological constraints on egg size: A challenge to optimal egg size theory? Proc Natl Acad Sci USA 84: 4145-4147.

Correa HB. 1978. Contribuição ao estudo dos quelônios amazônicos registrando casos de albinismo observados em Podocnemis expansa (Schweigger 1812) e Podocnemis sextuberculata (Cornalia 1849) (Testudines, Pelomedusidae). Bol Tecn IBDF 5: 3-25.

Coutinho JMS. 1868. Sur les tortues de l'Amazone. Bull Soc Impér Acclim 5: 147-166.

Dixon WJ AND Massey FJ. 1983. Introduction to statistical analysis. Fourth ed. New York etc.: McGrawHill. xv +678 p.

FACHIN A. 1982. Contribución al conocimiento de la "taricaya" Podocnemis unifilis Troschel 1848 (Chelonia: Pelomedusidae) en el Rio Samiria, Loreto, Perú. Tesis de grado, Univ. Nac. Amazonia Peruana. vi + $75 \mathrm{p} .$, pls.

FACHIN A. 1993. Caracteristicas de Podocnemis unifilis (Reptilia, Testudines) en el Rio Samiria, Loreto. Bol Lima 87: 69-74. 
Foote R. 1978. Nesting of Podocnemis unifilis (Testudines: Pelomedusidae) in the Colombian Amazon. Herpetologica 34: 333-339.

Humboldt A von. 1814. Voyage, tome 1 In: A von Humboldt and AJA Bonpland. Voyage aux régions equinoxiales du Nouveau Continent...

Humboldt A von. 1859-1860. Alexander von Humboldt's Reise in die Aequinoctial-Gegenden des neuen Continents. In deutscher Bearbeitung von Hermann Hauff. 4 volumes. Stuttgart: JG Cotta (see Vanzolini 1977a: 20).

Humboldt A von ANd Bonpland AJA. 1805-1831. Voyage aux régions equinoxiales du Nouveau Continent fait en 1799... 24 vols. Paris.

IICA-TrópICo 1973. (Instituto Interamericano de Ciencias Agricolas)/Brasil, Ministério da Agricultura. Relatório do simpósio sobre fauna silvestre e pesca fluvial e lacustre amazônica. Informe de Conferencias, Cursos y Reuniones 26. 2 vols. (mimeo).

Licata L and Elguezabal X. 1997. Management plan for the giant Amazonian turtle, Podocnemis expansa, in De La Tortuga Arrau Wildlife Refuge, Orinoco River, Venezuela, 171-173. In: J van AbBema (ed.), Proceedings: Conservation, restoration and management of tortoises and turtles.

Medem F. 1960. Datos zoo-geográficos y ecológicos sobre los Crocodylia y Testudinata de los rios Amazonas, Putumayo y Caquetá. Caldasia (Bogotá) 8: 341-351.

Medem F. 1964. Morphologie, Ökologie und Verbreitung der Schildkröte Podocnemus unifilis in Kolumbien (Testudinata, Pelomedusidae). Senckenberg Biol 45 (3/5): 353-368.

Medem F. 1969. Estudios adicionales sobre los Crocodylia y Testudinata del Alto Caquetá y Rio Caguán. Caldasia (Bogotá) 10(48): 329-353.

Mondolfi E. 1955. Anotaciones sobre la biologia de tres quelonios de los llanos de Venezuela. Mem Soc Ci Nat La Salle (Caracas) 15(42): 177-183.

Mosqueira-Manso JM. 1945. Las tortugas del Orinoco. Ensayos biológicos de la Arrau (Podocnemis expansa). III Conferencia Interamericana de Agricultura, Cuadernos Verdes 2: 43p.

Naturatins. 2001. Projeto Quelônios do Tocantins, UHE Luis Eduardo Magalhães. Relatório final. Pal- mas: Instituto Natureza do Tocantins, Naturatins 14p.

Pritchard PCH and Trebbau P. 1984. The turtles of Venezuela. Society for the Study of Amphibians and Reptiles. viii + 403p., pls.

RAMIREZ-E MV. 1956. La tortuga: estudio biológico de la tortuga "arrau" del Orinoco, Venezuela. Agric Venezol 21(190): 43-61.

Roosenburg W and Dunham AL. 1997. Allocation of reproductive output: egg - and clutch-size variation in the diamondback terrapin. Copeia 2: 290-297.

Rowe JW. 1994. Reproductive variation and the egg sizeclutch size trade-off within and among populations of painted turtles (Chrysemys pictabellii). Oecologia 99: 35-44.

Roze J. 1964. Pilgrim of the river. Nat Hist (New York) 73(7): 35-41.

SchweIgGer AF. 1812. Prodromus monographiae Cheloniorum auctore Schweigger. Arch Naturwiss $\mathrm{u}$ Math 1: 271-368, 406-458.

Sites JR JW, Fittzsimmons NN, Silva JR NJ and Cantarelli VH. 1999. Conservation genetics of the giant Amazon River turtle (Podocnemis expansa; Pelomedusidae) - inferences from two classes of molecular markers. Chelon. Conserv Biol 3: 454-463.

Smith CC and Fretwell SD. 1974. The optimal size and number of offspring. Amer Nat 108(962): 499-506.

SoINI P. 1983. Ecologia reproductiva de la taricaya (Podocnemis unifilis) y suas implicaciones para el manejo de la especie. Informe de Pacaya 9: $43+$ (14)p. (mimeo).

Souza RR AND VogT RC. 1994. Incubation temperature influences sex and hatchling size in the Neotropical turtle Podocnemis unifilis. J Herp 28 : 453-464.

SPIX JB. 1824. Species novae testudinum quas in itinere annis MDCCCXVII-MDCCCXX per Brasiliam... colligit et descripsit... Monachii: CFP de Martius... 24 p., pls.

Thorbjarnarson JB, Peres N and Escalona T. 1993. Nesting of Podocnemis unifilis in the Capanaparo River, Venezuela. J Herp 27: 344-347.

Troschel FH. 1848. Amphibien. In: R SchomburgK. Versuch einer Zusammenstellung der Fauna und Flora von Britisch-Guiana. Thl. 3. 
Valenzuela N. 2001. Genetic differentiation among nesting beaches in the highly migratory giant river turtle (Podocnemis expansa) from Colombia. Herpetologica 57: 48-57.

Valle RC, Alfinito J and Silva MMF. 1973. Contribuição ao estudo da tartaruga amazônica, vol. 2, p. VIII E 65-87 In: IICA/Brasil, MA, Relatório do simpósio internacional...

Van Abbema J. (ed.), 1997. Proceedings: Conservation, Restoration and Management of Tortoises and Turtles - an international conference, 11-16 July, 1993, State University of New York, Purchase, New York, USA. New York: New York Turtle and Tortoise Society and The MCS Turtle Recovery Program. xxi + 494 p.

Vanzolini PE. 1977a. An annotated bibliography of the land and fresh-water reptiles of South America (1758-1975). Vol. I (1758-1900). São Paulo: Museu de Zoologia da Universidade de São Paulo. iv + 186p.

VANZOLINI PE. 1977b. A brief biometrical note on the reproductive ecology of some South American odocnemis (Testudines, Pelomedusidae). Papéis Avulsos de Zoologia 31(5): 79-102.
VAnZolini PE. 1981. The scientific and political contexts of the Bavarian Expedition to Brazil. Introduction. In: K Adler (ed.), Herpetology of Brazil, ... p. ixxxix.

VAnZolini PE. 1993. Métodos estatísticos elementares em sistemática zoológica. S. Paulo: Hucitec. 130p.

Vanzolini PE. 2001. On the eggs of Brazilian Podocnemis (Testudines, Podocnemididae). Biol Geral Experim 2(2): 3-17.

VeCCHI NO. 1978. Trombetas, o rio das tartarugas. Troféu, S. Paulo, 84: 30-39.

Wermuth H and Mertens R. 1996. Schildkröten, Krokodile, Brückenechsen. Jena: Gustav Fischer. xxvi + 506 p. (Nachdruck der Ausgabe von 1961 mit einem ergänzenden Nachtrag von... Fritz Jürgen Obst...).

ZAR JH. 1999. Statistical analysis. Fourth edition. Upper Saddle River, New Jersey: Prentice-Hall: xi + $661+$ $212+11+20+23 p$ 